\title{
Market and Institutional Determinants in the Regulation of Conveyancers
}

\author{
Benito ARRUÑADA*
}

\section{Abstract}

Demand for law professionals in the conveyancing of property is decreasing because of market and institutional changes. On the market side, many transactions feature large, wellknown parties and standardized transactions, which make professionals less effective or necessary for protecting the parties to private contracts. On the institutional side, public titling makes it possible to dispense with a broadening set of their former functions. Recording of deeds made professionals redundant as depositories of deeds and reduced demand for them to design title guarantees. Effective registration of rights increasingly substitutes professionals for detecting title conflicts with third parties and gathering their consent. Market changes undermine the information asymmetry rationale for regulating conveyancing, while institutional changes facilitate liberalizing not only conduct but also license regulations. These arguments are supported here by disentangling the logic of titling systems and presenting empirical evidence from the European and USA markets.

JEL Classification: K11, K12

Keywords: Lawyers, notaries, property rights, real estate, transaction costs.

\footnotetext{
* Department of Economics and Business, Universitat Pompeu Fabra. Mail: Trias Fargas, 25. 08005-Barcelona, Spain. E-mail: benito.arrunada@upf.edu. Http://www.econ.upf.es/ arrunada. The author thanks John D. Cooke, Fernando Gómez Pomar, Joyce D. Palomar, Pamela O’Connor, Ruth Paserman, Mark C. Schechter, Frank Stephen, Christine C. Wilson and participants at the Ninth EU Competition Law and Policy Workshop, the Eigth ISNIE conference and Université de Paris X for their comments and Ana Estrada for her research assistance. Usual disclaimers apply. This work has received financial support from the Spanish Ministry of Education, through grant SEJ2005-03871/ECON and the European Commission through the Integrated Project "Reflexive Governance in the Public Interest" (CIT3-513420).
} 


\section{Introduction}

\section{A. Motivation}

Participation by different kinds of lawyers is required to contract real estate in many countries. In others, including 16 states in the USA, lawyers or licensed conveyancers are the only professionals who can help parties to write contracts for sale, transfer deeds or both. Notaries enjoy an even wider reserved practice in most of Europe, with the general exceptions of Ireland, the UK and Scandinavia and particular exceptions for different transactions in most other countries. Their monopoly as a profession is grounded on the legal requirement of prior notarization for filing many documents in public registers and on the privileges enjoyed by notarized deeds in some judicial procedures; ${ }^{1}$ and it is protected by a full set of restrictions, including a fixed number of notaries, fixed prices and prohibitions on advertising and organization of notary offices. ${ }^{2}$

Various international initiatives have pointed out that such mandatory intervention by civil law notaries is inefficient. In its first Doing Business report, the World Bank suggested that notaries are one of the main culprits for the greater cost and longer duration of company incorporations in civil law countries (2004, pp. 26-27). Together with pharmacies, notaries also figured prominently as the most regulated profession in the study commissioned by the European

1 The traditional source of notaries' monopoly power was the privileged evidentiary status that law and courts often concede to notarized documents. This procedural difference is valuable for parties to enhance the enforceability of contracts (e.g., mortgage foreclosure), especially in countries with slow courts and whatever the substantive evidentiary value which is in fact added or not by notarization. However, most notarized documents are now filed in land and commercial registers, for which notarized documents are also required. Privileged access to public registers has therefore become the main source of notaries' monopoly power to the extent that courts rely on the information in the registers.

2 In addition to regulatory monopoly, the market for conveyancing services is prone to suffer from substantial cognitive failure on the part of customers because they purchase conveyancing services jointly with a very costly purchase. According to prospect theory (Kahneman and Tversky, 1985), this may cause a cognitive bias, as the cost of conveyancing is only a small loss integrated into a much greater loss. Furthermore, the addition of a relatively small amount to the huge cost of most real estate transactions could make such small amounts difficult to perceive (Thaler, 1980). 
Union Competition DG on the liberalization of professions (Paterson, Fink, and Ogus, 2003, pp. 51-57; Monti, 2003, p. 2; Commission of the European Communities, 2005).

Both of these initiatives make a good case but also forget two key points. By focusing on notaries, Doing Business disregards the fact that something similar can be argued about lawyers where their intervention is still de iure or de facto mandatory. Furthermore, as we will see, the function of notaries in some civil law countries is now increasingly similar to that of notaries in common law, in that they often act as mere authenticators. ${ }^{3}$

By paying insufficient attention to the nature of the service in question, the EU risks advancing incomplete reforms that might be inconsistent with the functions that professionals are entrusted to perform, ${ }^{4}$ as shown by the mixed results of liberalization efforts. These reforms typically liberalize some rules on professional conduct, such as prices and advertising, but keep the practice reserved for the professionals. Such partial liberalization may be inconsistent because licensing is now unnecessary for professionals to provide quality private services while freeing conduct makes it well nigh impossible for conveyancers to provide external effects. This is confirmed by the observed consequences of liberalization in the Netherlands, where most notaries' prices were freed after 1999 and some freedom of entry allowed into each others' reserved markets. The result was that cross subsidies were reduced, resulting in higher fees for family services and lower fees for high-price transactions (Kuijpers, Noailly and Vollaard, 2005). Consistent with our argument, no change was detected in perceived quality by notary clients but the quality attributes controlled by the land register did decline (Nahuis and Noailly, 2005), confirming that greater competition leads to weaker control of externalities. Casual evidence on Spain follows the same pattern after partial liberalization of entry in 1999 and of prices in 2000 .

These issues are important for transition and developing economies, where such mandatory intervention often increases transaction costs exorbitantly, as forcefully argued by Hernando de Soto $(1989,2000)$ and often reported in the news. ${ }^{5}$ As a consequence, it hinders the enforcement of property rights and the use of land as collateral for credit, a much-needed outcome.

3 See Section III and notes 15 and 20 below. This seems to follow a historical tendency, because notaries' functions in common law were also wider in the past: see, for instance, Closen and Dixon (1992, p. 875, n. 10), on how US notaries prepared and kept copies of documents around 1900; Pulling (1862, p. 10, n. u), on preparation of documents by $19^{\text {th }}$ century English notaries; and Brockman (1997), for the case of British Columbia.

4 See Arruñada (2006) for an application of this argument to the professions in general.

5 For example, authenticating documents for corporate loans entitled Hungarian notaries to $0.1 \%$ of the sum involved ("Your Papers Please," The Economist, November 20, 1997). In another notorious example, Italian notaries intervened until 2006 in all sales of used cars, and their prices for real estate transactions are so high that parties often avoid them by the old and cumbersome technique of filing a simulated lawsuit, a primitive technique similar to the fine used in old England from the $12^{\text {th }}$ century until 1833 (Kolbert and Mackay, 1977, p. 241), in colonial Massachusetts (Konig, 1974, pp. 160-61) and even in biblical times (Ellickson and Thorland, 1995, p. 385). 


\section{B. A guide to changes in conveyancing}

Demand for conveyancing services has seen substantial changes, rooted in the development of land titling systems as well as in the radical transformations experienced over the last two centuries by parties, technology and transactions in the conveyancing market.

At the institutional level, states have developed public titling systems which effectively make either property contracts or property rights public, reducing the threat that hidden property rights previously posed to acquirers and, consequently, most of the demand for conveyancing services that, to some extent, provided a substitute service, including the avoidance of title conflicts, the design of title guarantees and acting as title depositories. More recently, information technologies have provided an alternative technology - electronic notarization - that in essence allows parties to disintermediate professional authenticators of documents and avoid the need for a physical meeting to sign the contract.

At the market level, the emergence of large firms in mortgage lending, real estate development and property transaction mediation has reduced the comparative advantage of conveyancers because such large firms are in a good position to guarantee quality to their customers and to achieve economies of scale and lower costs in the preparation of contracts. A similar consequence has resulted from changes in the nature of transactions, which have become more standardized as a consequence of the development of mass markets and mandatory legislation, both of which reduce the demand for tailoring contracts to individual needs.

These sets of changes and their consequences for conveyancing will be analyzed in the next two sections. The paper ends with a discussion of future tendencies and policy issues.

\section{Changes in conveyancing driven by the evolution of titling systems}

\section{A. Property rights under privacy and publicity}

Rights on land and some other durables can be enforced as "property" or in rem rights, claimable against the asset itself and therefore valid against all persons. Contrary to contractual or personal rights, property rights "run with the land," meaning that they survive unaltered through transactions dealing with other rights on the same land. For example, a mortgagee keeps her claim on the land even after the mortgagor sells it. Property rights also oblige all people: the 
new owner who has purchased the land is obliged to respect both the mortgage and, in particular, the right to foreclose in case the guaranteed debt is not paid. ${ }^{6}$

When the law enforces a right as a property right, consent of the right holder is required for the right to be damaged. This requirement of consent ensures enforcement because transactions among parties do not convey property rights with the promised in rem extent until all affected right holders have consented. However, such survival of property rights after conveying the land requires costly institutions and procedures in order to search, bargain and contract for the relevant consents. An obvious cost comes about because the possibility of hidden property rights increases the information asymmetry between the conveying parties: in the absence of consent from the hidden right holder, the acquired asset is burdened with the hidden right and the acquirer has instead a contractual right against the seller. More generally, the need to know which conflicting property rights exist, finding out who their right holders are, bargaining with such right holders to obtain their consent and formalizing an agreement with them, all increase the costs of conveying and transforming rights.

Two main legal regimes have been applied for enforcing property rights: privacy and publicity.

Under the tradition of private conveyance that was dominant in Europe until the $19^{\text {th }}$ century, earlier private contracts on land had in rem effects on later acquirers even if such contracts were kept secret. In cases of conflict, courts established title on the basis of evidence on possession and on past transactions (the "chain of title"), whether or not such transactions had remained hidden, and set priorities among claims according to their dates of contract. These two solutions did not, however, reduce transaction costs substantially. On the one hand, physical possession does not inform about abstract rights, like ownership and mortgages. When possession is used to establish ownership, specialization of ownership and control is hindered because it subjects owners to the risk that possessors might use their position to acquire ownership or convey owners' rights. Similarly, using land as collateral for credit requires transferring ownership or

${ }^{6}$ My previous work on notaries (Arruñada, 1996) was implicitly grounded on the concept of property rights most commonly used by economists, which does not distinguish between what in law are "property" (that is, in rem) and "contractual" (personal) rights. As a consequence, it disregards the incapacity of competing notaries to be independent of the parties and control legality because, typically, parties are free to choose notary. This incapacity worsens when prices are freely set by notaries. Even notaries who act impartially face substantial limitations in performing their function because they act in the interest of the parties, and controlling legality essentially means defending the interest of third parties. These limitations lie in the free choice of notary by the parties (so that effective standards are set by the professionals who control the least) and become more binding with increased competition. Conveyancers are motivated to prevent potential damage to the contractual parties, but only to the extent that effective control may be performed subsequently by judges (under recording) or it is performed immediately by registers (under registration). Arruñada (2003a), which is the basis for this section, clarifies this crucial distinction, one that is often overlooked (for instance, by Van den Bergh and Montangie, 2006a and 2006b). It also reinforces the argument in Arruñada (1996) that the comparative advantage of notaries lies in the economies of scope reached by impartial lawyering, which is often artificially forbidden by the Bar in common law countries (see n. 21). For a comparison of titling systems from a public policy perspective, see Arruñada and Garoupa (2005). 
possession to the lender, thus leaving the debtor subject to the lender's moral hazard. On the other hand, some of these problems are overcome by embodying abstract rights in titles and evidencing rights with the chain of title, which makes it easier to separate ownership and control. Titles also serve to enforce securities, by depositing the titles with the lender, even if this burdens the debtor with the lender's moral hazard and causes switching costs that make second mortgages difficult.

The remaining difficulties of contracting property rights under privacy were such that modern systems of property law started to induce or require the publicity of contracts in land as a prerequisite for them to attain in rem effects. Under a system of publicity, right holders risk losing in rem effects if they keep their rights private. For example, a buyer may lose his land if the seller sells it again to an innocent third party who publicizes her acquisition first. That is, private contracts may create obligations among the parties (the buyer would have a claim against such a fraudulent seller) but do not bind third parties - in this case, the later, innocent buyer. Publicity therefore facilitates the search of which property rights are held by whom, making it possible to reach consent ex ante, purging titles, and reducing information asymmetries between transactors.

Modern legal systems differ in the kind of publicity they provide. Systems of recordation of deeds (used in most of the US, part of Canada, France and some other countries) simply enroll and keep private contracts ("title deeds") and thus provide evidence on property claims. This evidence is then used by judges to allocate property rights in case of litigation ex post. Furthermore, courts determine the priority of claims from the date of recording in the public office and not from the date of the contract. This "first in recording first in right" priority rule effectively motivates parties to record from fear of losing title through, for example, a wrongful second sale. It also makes it possible to produce information on the quality of title ("title reports"), by having an expert examine the public record of deeds and not merely - as under privacy - those deeds in the grantor's chain of title. In fact, whole industries have developed to supply these title assurance services: notaries in, for example, France and abstractors, attorneys, title insurance agents and title insurance underwriters in the US.

As in recordation of deeds, registration of rights also applies this priority rule: ${ }^{7}$ private contracts gain provisional priority when they are first lodged in the register. They are then subject, however, to substantive review by the registrar, to detect any potential conflict with other property rights. Rights are registered only when the registrar determines that they do not affect any other property right or the holders of affected rights have consented. Otherwise, registration is denied and the parties have to restructure their contract or obtain the relevant consents. For registered rights and given that any contradictions have been purged, the register is able to provide "conclusive," "indefeasible" title, meaning that a good faith buyer acquires a property right if the purchase is based on the information provided by the register.

${ }^{7}$ Registers of rights developed within the German legal tradition, during the 19th century (Prussia, 1783; Austria, 1794; Spain, 1861; Australia, 1875; Germany, 1900) and are now used in most of the world, including the Australian "Torrens" variety, adapted from the register of ships in Hamburg, which has been introduced in some other Common Law jurisdictions. It is also the system being introduced in most former Socialist and developing countries. 


\section{B. Demand for conveyancing services in the three titling systems}

All three systems share functional similarities: all three are based on enforcing individual consent as a requirement. As a consequence, contracting proceeds in two steps: first, parties agree to the transaction; second, they gather the consent of affected right holders. By making this gathering of consent more or less difficult, the three titling systems induce different demands for "conveyancing services", these being understood as services provided by notaries, lawyers or other professionals that support contracting between the parties.

\section{Privacy}

Under privacy, property rights would eventually be enforced in rem even if the transaction remained hidden. By themselves, private contracts could not damage third parties. For instance, if $B_{2}$ is purchasing land from $O, B_{2}$ should be worried that $O$ might have previously sold the land to $B_{l}$ or mortgaged the same land to $L$. However, $B_{l}$ is fully protected because, assuming neither of the two buyers took possession, the courts will establish title according to the date of the contract and give the land to $B_{1}$, with $B_{2}$ having only a contractual claim on $O$. Buyer $B_{1}$ should be worried, however, about the possibility that $O$ and $B_{2}$ may fraudulently antedate their contract.

This system maximizes the complexity of conveyancing services. It first generates demand for lawyers to design and evaluate title guarantees offered by sellers and third parties, which, even if they do not protect buyers in rem, at least provide some protection in personam.

Second, reducing transaction costs when rights are embodied in titles also requires protecting the titles against fraud. ${ }^{8}$ From early times, legal systems required the presence of witnesses, surely the simplest solution, often qualified in terms of number, age, expertise and authority. In addition, titles are protected by requiring that specialists (lawyers or notaries) are involved in producing them. A common solution to make fraud difficult is for grantees and mortgagees to demand delivery of the full chain of titles from grantors and mortgagors, so that the risk of previous competing transactions is reduced and later transactions will require faking a full chain of titles. In a sense, the chain of titles is used as a private record but without any guarantee that it is exhaustive.

The role of conveyancers is greatest under the privacy system, because they act as both producers and depositories of the main body of evidence used to establish title. In this context, reducing competition between professionals serves two purposes.

First, sharing information among conveyancers will substantially save on the costs of structuring new deals and make them more secure. This process could be observed recently in Andorra, a small independent country between France and Spain, which still applies a relatively pure system of Roman Law, including privacy for real estate transactions. The few Andorran notaries started to share information on mortgages after a new regulation was enacted in 1998.

8 The pervasiveness of compulsory proof and the ingenuity applied to developing it attests to the importance of restraining fraudulent conveyance. For historical references, see Arruñada (2003, p. 407). 
Second, reducing competition will lessen the incentives of conveyancers to cheat each other, and may provide some support for the protection of third parties against fraud. The system hinges, however, on conveyancers dating deeds faithfully. For instance, notaries chronologically enter all documents into the notary's protocol, which provides an additional safeguard on the dating of documents. But the system may be prone to fraud as can be seen in some Latin American countries where, given the sorry state of the land registers, judges tend to pay some attention to the date of deeds, falling back de facto into a privacy system and thus increasing the motivation to fraudulently antedate deed notarization, apparently a common occurrence.

\section{Recording}

Under recording, private contracts and other documents are filed in a public office that does not perform any control but for the date of the document and the formalities required to index it. The need to safeguard the contract is reduced with respect to privacy because this public control avoids one of the typical frauds under privacy - antedating a sale or a mortgage. The role of conveyancers as depositories of documents also becomes less relevant and tends to disappear. Something similar happens to the demand for writing sophisticated title guarantees, to the extent that the filing system makes them superfluous.

Recording does not, however, avoid the risk of a second sale or mortgage. In the previous example, the recording office will not object to recording the second sale by $O$ to $B_{2}$, even if the first sale to $B_{1}$ is already on record. Nor will it object to recording a sale to $B_{2}$ free of charges even if a mortgage of the land to $L$ has previously been recorded. Buyers will be aware that the apparent owner might have sold or mortgaged beforehand, and this deed might have been recorded and gained priority. Furthermore, finding the relevant information is not easy, because the public record contains a mix of relevant and irrelevant deeds resulting from all the previous transactions and the deeds are indexed on a personal basis, using name or grantor-grantee indexes.

To avoid nasty surprises and report on the quality of title, parties will retain some sort of title agent to search the record fully and detect any previous sales or other title cloud. Consequently, the role of these title agents in searching and reporting on the quality of title remains important, creating a substantial demand for conveyancers.

The importance of their function will be smaller, however, the better the organization of the recording office. Two innovations with respect to pure recording as described above are crucial: control by the recordation office that the grantor has good title and use of a tract index, both of which are applied, for example, in France but not in most of the US.

First, the quality of the recorded information improves substantially when the recordation office requires that only those already recorded as right holders can be grantors in a new transaction, thus eliminating the risk of second sales. Similarly, a well-functioning recording office will control lender's consent before canceling a mortgage.

Second, the use of tract indexes, instead of relying on personal indexes of grantors and grantees, is essential for avoiding filing errors. When the records are poorly organized (as in many US counties), it seems natural to develop private "title plants," that is, well-organized replicas of the public records. The investment required to build such plants will move the 
comparative advantage from individual title agents to the operators of the plants, who then play the leading role in the whole process.

\section{Registration}

Under registration, the register controls not only the date but also the content of the private contract and any potential collision with property rights held by third parties, which drastically diminishes the demand for high-value services in the preparation of the private contract. There is no role for title guarantees, and the register itself performs the title search and produces a title certificate.

Moreover, the switch from property to liability rule - that is, the fact that, under registration, an innocent purchaser who relied on the register keeps the land to the detriment of the "true" legal owner - means that notaries are no longer indirectly motivated by the interest of their clients to identify and avoid potential title defects (as they are under privacy and recording). Notaries tend, rather, to become the advocates of the parties to the register, which is now the main instance protecting the interest of third parties, whose property rights would become contractual rights in case of registration error. In other words, given that under registration courts adjudicate conflicting rights by applying a rule of liability, parties tend to encourage conveyancers and title examiners to disguise the facts before the register instead of preventing such title conflicts, a change that further reduces the former gatekeeping function of these professionals.

Understandably, the demand for conveyancers to authenticate contracts also diminishes, for several reasons. First, registers are well placed to authenticate documents by themselves. In contrast to mere recording offices, registers perform a highly technical task when controlling the legality of private contracts. The knowledge and safeguards necessary to perform such a task can easily be applied to a relatively less technical task such as authentication. This is shown empirically by the existence and effectiveness of registers of rights in Scandinavian countries, which require neither notarized deeds nor intervention by lawyers but simply rely on witnesses. Second, banks are now the real experts in identifying individuals, and this also diminishes the role of lawyers and notaries in contracts to which banks are parties. Third, the development of digital authentication (often called electronic notarization) allows parties to disintermediate the notary and dispense with witnesses for authenticating purposes. This may even be more effective than traditional methods, now that urban lawyers and notaries do not personally know most of the parties, as they did in the past, and have to rely on indirect proof such as ID cards. (This lack of personal knowledge also hinders professionals' ability to evaluate the parties' mental capacity.)

Nor is it necessary for lawyers to be involved in the start-up stages of a registration system. Given that start-up costs are high, if a reliable supply of high-quality conveyancing services is available, a way of saving on start-up costs could be to make use of conveyancers to purge titles and improve the quality of deeds, as claimed by solicitors in the transition between titling systems in Ontario. ${ }^{9}$ However, provisional registration of possessory rights provides an

9 Troister and Waters (1996). 
alternative, cheaper and probably equally effective solution. ${ }^{10}$ Furthermore, reliance on conveyancers for the start-up stage poses the obvious risk that this mandatory intervention may extend beyond their useful life, as a functional, steady-state register clears titles on registered land effectively and at low cost without such intervention.

This shrinking of conveyancing under registration helps to explain why conveyancers often oppose registration. Indeed, conveyancers have often managed to impede the development of registers, monopolizing entry into existing registers or debasing their legal effects - for instance, by reinforcing the effects of possession or title deeds against those of the register. ${ }^{11}$ Partly as a consequence of this, many real systems are hybrids in transition (Arruñada, 2003). In particular, registration systems are often plagued by the presence of "overriding interests": rights which are enforced in rem despite not being registered (for instance, due taxes and possessory rights) or rights filed in separate administrative registers (as typically happens with municipalities' zoning and preemption rights). This implies that in many countries the role of conveyancers is also a hybrid one, playing a greater role with respect to unregistered rights. For example, French notaries play a preventive role, similar to that of US title insurers with respect to the preemption rights held by tenants and municipalities (Willman and Pillebout, 2002), but very different with respect to ownership rights, because the French recording office checks that the grantor has good title, in application of the règle de l'effet relatif.

\section{Evidence on the substitution between registration and conveyancing}

One of the previous claims is amenable to empirical testing: the reduction that registration causes in the scope of conveyancing services, which can be observed by comparing the transactions costs of property transactions in countries with different titling systems. As shown in Table 1, in countries with recording of deeds, conveyancing services for typical purchase and mortgage transactions are much more costly than in countries with registration of rights. In the five countries with registration of rights, the cost of conveyancers is only $0.36 \%$ of the value of the property for contracting a purchase and $0.14 \%$ for a mortgage, while in the four countries with recording of deeds, the costs are more than five and eight times higher, reaching $1.9 \%$ and $1.13 \%$, respectively. ${ }^{12}$

10 The case of Spain is analyzed in Arruñada (2003b).

11 For example, it has been argued that one of the reasons why Torrens registration failed in the US was the opposition of lawyers, abstracters and title insurers (for example, Bostick, 1987, p. 64, n. 23, citing Quintin Johnstone; Dukeminier and Krier, 1998, p. 721). Similarly, English solicitors stopped registration in the $19^{\text {th }}$ century (Anderson, 1992) and finally delayed its expansion for a century by requiring county votes (Bostick, 1987, p. 59, n. 7). Notaries' resistance to change has often also been linked to their monopoly. See, for example, the cases of France in Suleiman (1987, pp. 92-106), Belgium in Raucent (1998, p. 129) and Spain in Arruñada (2001).

12 Schmid et al. (2006) find that systems that are supposedly highly regulated (Germany, Spain) exhibit low legal costs. This finding is surprising only within their framework because they classify conveyancing systems according to a formal feature - intervention by different kinds of conveyancers (notaries, lawyers, real estate agents) — instead of the more substantive issue of the 
These differences in the prices of conveyancing are consistent with two complementary interpretations. First, registration drastically reduces the value added by conveyancers. Second, in countries with recording of deeds, conveyancers have been successful in both impeding the introduction of the most efficient technology (registration) and in rent-seeking, therefore enjoying higher prices. The efficiency of registration is supported by the fact that it reduces the cost and value of conveyancing without increasing the cost of public titling. On the contrary, the data shows that the costs of registers under registration of rights are lower $(0.1 \%$ for purchases and $0.22 \%$ for mortgages) than those of recorders under recordation of deeds $(0.9 \%$ and $0.23 \%$, respectively). If confirmed, this cost advantage of registration would make the theoretical comparison in Arruñada and Garoupa (2005) far more favorable to registration, at least in a steady state scenario which does not consider the costs of initial registration. It also clarifies the options faced by policy makers when reforming these systems.

\section{Changes in conveyancing driven by changes in parties and transactions}

In parallel with the development of titling systems, the characteristics of parties and transactions have changed substantially, dramatically reducing the comparative advantage of conveyancers for helping parties to property contracts.

The professional structures of the conveyancing industries were set up in the $19^{\text {th }}$ century, at a time when most contracting took place between relatively equal, small parties, mostly individuals, who were free to contract according to their wishes in the shadow of default law. These features of party equality and contractual freedom have changed substantially since then, altering the kind of conveyancing support services needed and making it possible to provide them more cheaply.

This section will show that the growing dominance of large parties has reduced the importance of information asymmetries between parties to the private contract and the locus of economies of scale in contract preparation. The standardization and mandatory regulation of transactions has lessened the demand for tailoring private contracts to the parties' specific circumstances.

type of land register existing in each country, which defines by default the function actually performed by conveyancers, whether they are called lawyers, notaries or estate agents. For the same reason, their consideration of the Netherlands as a unique system is widely off the mark, especially considering the limitations of the Dutch liberalization process. 


\section{A. Parties' characteristics}

Today, in a large number of property contracts, at least one of the parties is a firm playing repeatedly in the market, mainly lenders, property developers and real estate agents. The size and continuous presence of these firms in the market makes it possible for them to reach economies of scale in the preparation and safeguarding of contracts, reducing the demand for professional conveyancers.

In practice, therefore, many property contracts have become contracts of adhesion. This is especially the case for mortgage deeds, most of which are now written by lenders or, in the US, by secondary mortgagee lenders (DOJ, 1999, p. 7), and filled in with the help of specialized software packages. ${ }^{13}$ This transformation into contracts of adhesion may cause new problems, which cannot be properly discussed in this paper, ${ }^{14}$ but, whatever the seriousness of these problems, such transformation minimizes the role of professional conveyancers in drafting the contract. 15

Similarly, because of their repeated presence in the market, large parties have additional incentives to invest in reputation and to act fairly. They are therefore in a good position to be impartial within specific transactions, ${ }^{16}$ exerting contractual and even quasi-judicial tasks. ${ }^{17}$ In

${ }^{13}$ For many years firms such as International Document Services (http://www.idsdoc.com, visited July 1, 2004) have been providing online software that serves to prepare mortgage forms that are updated regularly to comply with the requirements of secondary lenders (see, for example, "Partnership links doc prep and RE," Origination News, 8 (5), 13, February 1999).

${ }^{14}$ It has been argued, for instance that adhesion contracts pose a typical "lemons problem" (Katz, 1990), but competition will motivate drafting firms to invent communication arrangements that make it profitable to improve the clauses in such contracts efficiently (that is, including actual information and the learning costs suffered by all parties). The same counterargument applies to the bounded rationality arguments made popular by Korobkin (2003), among others.

15 This effect is often admitted by the professionals, who consider that it has debased their function. For instance, a prominent Spanish notary writes that "the massive granting of certain types of contract, specially deeds of sale and mortgage loans, as well as company incorporations and transformations, has had a dual effect: on the one hand, it has deprived the Notary of an essential part of his function, the writing of the document, which is invariably granted on the basis of a draft produced by the legal services of the granting organization; on the other, it limits participation by the Notary, throughout the 'transaction path,' to the single moment of authorizing the deed" (López Burniol, 1994, p. 129). See also note 20.

16 Reaching this position of impartiality requires effectively solving the agency problem within firms: for example, providing powerful short-term incentives to employees will often motivate them to exploit customers even when this is detrimental to the firm. In a competitive environment, the incentives are present, however, for firms to trade off the different contractual problems with customers and employees, choosing the right mix of safeguards.

17 On this "asymmetric contracting", see Arruñada (2000), and Arruñada, Garicano and Vázquez (2001). 
fact, the contractual functions of these agents go further than the preparation of documents. Consider, for instance, the procedures for non-judicial foreclosure of mortgages in the US, the traditional functioning of US banks as notaries, ${ }^{18}$ or the unilateral setting of the final debt by lenders within the foreclosure procedure in Spain. Participation by reputed parties therefore diminishes the role of lawyers in both the preparation and safeguarding of all but the highestvalue contracts. ${ }^{19}$

Furthermore, the arrival of large, reputed parties entails a basic change in the way transactions are safeguarded against opportunism. Traditionally, conflicts of interests in conveyancing were overcome by relying on adversary lawyering in common law and notaries' impartiality in civil law. The presence of large, reputed parties substantially modifies both arrangements. First, because such parties provide assurance by themselves. Second, because their volume endangers the impartiality of notaries who, consequently, often add little to the safeguard provided by the reputation of such large parties. ${ }^{20}$ In some countries, a tendency is observed towards the presence of large parties as ultimate assurers and the increasing role of lawyers as impartial representatives of several parties. ${ }^{21}$

18 Understandably, a US bank was the pioneer in providing digital signatures, as "banks' capital strength, fiduciary tradition, and long involvement with electronic services and data base management create a natural affinity for providing electronic authentication services" (Corwin, 1998).

19 On the historic role of notaries in overcoming information asymmetries, see Hoffmann, Postel-Vinay and Rosenthal (1998, 2000).

20 Prominent notaries also acknowledge this dependence "in all those very numerous cases in which the deeds are written up in accordance with drafts 'imposed' by one of the partiesgenerally, a large financial institution-, constituting authentic contracts of adhesion" (López Burniol, 1994, p. 142). Other notaries complain that they cannot "change a single comma in the clauses" of mortgage deeds (Berná and Crehuet, 2001). On the role of impartiality in the position of notaries, see Arruñada (1996, pp. 9-10) and Malavet (1996). Impartial intervention had not always been achieved by notaries, however, as shown by the common practice in some countries, where each party retains her own notary, such as in France (Paterson, Fink, and Ogus, 2003, p. 208) and British Columbia (Strandlund, 2000).

${ }^{21}$ On the possibilities and restrictions faced by US lawyers to act as impartial agents, representing not one but several parties, see Hazard (1978, pp. 56-68), Dzienkowski (1992) and rule 2.2 of the ABA code of professional conduct (2001), as well as an early analysis of the impartial role of some escrow agents in Burke and Fox (1976, pp. 333-345). English solicitors face similar restraints to represent several parties in a conveyance as a consequence of Rule 6 of the Law Society Practice Rules (1990), but with some exceptions, which require parties' consent, lack of conflict of interest and that the seller is not selling as a builder. There is no conflict of interest in acting for co-sellers, for co-purchasers, for the seller and seller's mortgagee, or for the purchaser and the purchaser's mortgagee, if the mortgagee is not a private person (Sarton, 2000, pp. 23-24). The rule was strengthened in October 1999 and additional rules were introduced at the same time by The Lenders' Handbook, a voluntary code of conduct adopted by the association of mortgage lenders to reduce conflicts of interest and instructing conveyancers acting on lenders' behalf in residential conveyances. An updated version is available at www.cml.org.uk/handbook (accessed December 29, 2006). 
Lastly, the comparative advantage of these large parties lies in their position as sellers of the fundamental services or goods that are the object of the contract (mortgage finance for lenders, mediation for real estate agents and buildings for land developers). Law professionals, alone or in partnership, are badly placed to counterbalance this advantage because of their specialization in contractual assistance, ${ }^{22}$ an ancillary service to the fundamental transaction. ${ }^{23}$

\section{B. Transaction characteristics}

Demographic change has also had an impact, as growing urbanization means that most transactions now deal with urban property, which is relatively more homogenous and presents fewer complications - for example, it is easy to identify and has fewer easements.

Standardization also comes about because of the more mandatory nature that the law adopted during the $20^{\text {th }}$ century. In the $19^{\text {th }}$ century, the law provided a set of default rules to the parties, allowing them to tailor their contracts freely to their particular needs. Mandatory law, in contrast, obliges parties to contract using fixed terms. The phenomenon is widespread: consider, for instance, the mandatory nature of legislation on mortgage foreclosures in most US states.

In some cases, the demand for legal services to support the contract changes in nature: instead of lawyers being required to tailor specific clauses, they are increasingly retained to comply with and circumvent mandatory rules. In this context, the relevance of civil law notaries has suffered more than that of other lawyers, as they often have little incentive to satisfy the demand for circumvention, because they enjoy a profitable monopoly, which was made more profitable by the lower costs brought about by standardization. They are, therefore, happy to provide compliance services, which add less value and can often be produced at lower cost by

22 French notaries are a remarkable exception as they are substantially involved in real estate agency. There are other cases on a smaller scale. In Spain, for instance, many notaries also provide and charge manual facilitation services for paying taxes and filing the deeds at the Land Register.

23 The merger of commercial notaries ("corredores de comercio") and standard civil notaries decreed by the Spanish government in 2000, provides some indirect evidence on the lack of comparative advantage of law professionals with respect to no-lawyers and large firms. Before the merger, commercial notaries enjoyed a monopoly in formalizing personal debt contracts while that of civil notaries mainly included mortgages and purchases of real estate. Some time after the merger, both types of notaries were allowed to notarize both sets of contracts. As a consequence, commercial notaries were soon notarizing as many real estate contracts as civil notaries, while civil notaries had achieved only a small share of personal debt contracts. In 2004, former commercial notaries already notarized an average of 2,092 civil contracts, not far from the 2,700 notarized by former civil notaries; the latter notarized only 755 personal credit contracts, far below the 2,574 of commercial notaries (data taken from the DGRN yearbook). This happened even though commercial notaries allegedly lacked proper legal training, which is consistent with our argument, as commercial notaries had stronger relationships with lenders and their entry into the civil notaries' traditional market was facilitated by the fact that mortgage contracts are largely standardized, written and safeguarded by lenders. 
paralegals, producing standardized clauses even when default law allows the parties to innovate. ${ }^{24}$

Both phenomena are consistent with the statistical evolution of the mix of services provided by Spanish notaries and their productivity, shown in Table 2. During the 20th century, standard services such as mortgages grew more than those which require more individualized tailoringthe estimated proportion of standardized documents rose from 38 to $62.5 \%$ between 1930 and 1998. Consistently, the apparent productivity of notaries increased more than sixfold in terms of documents and almost tenfold in terms of sheets, a clear indication that theirs has become more an industrial and clerical activity than a truly professional one. Spanish notaries processed an average of 10.67 documents a day in 1998, while the standard number of deeds per notary in Berlin was only 325 documents a year (Kuijpers, Noailly and Vollaard, 2005, p. 61), about one per working day. ${ }^{25}$

The diminishing role of law professionals in this field takes different forms in different jurisdictions. For instance, in many areas of the US, "attorneys are not normally involved in the home sale. ${ }^{26}$ For example, escrow agents or escrow companies in western states handle the paperwork to transfer title without any attorney involvement" (HUD, 2000, p. 2); in some states real estate agents act as dual agents of sellers and buyers (Pancak, Miceli and Sirmans, 1997). In residential transactions and with the exception of the 16 states in which attorneys still retain a monopoly over these services, it is usually the title insurance company which, through its own lay employees, searches the title, prepares the documents and closes the deal (ALTA, 2000). Something similar has happened in England, with the liberalization of conveyance after the Administration of Justice Act (1985), which created the profession of "licensed conveyancer", and with the arrival of the so-called "factory conveyancing" offered by several large national law firms for lender clients. Everywhere, lawyers have opposed these changes on the grounds of preserving quality. Evidence on a drop of quality is lacking, however. For instance, Palomar (1999) finds that the incidence of failures is not greater in those US states where non-attorneys are allowed to prepare the deeds and close the deals.

\section{Econometric evidence}

The econometric analysis presented in Table 3 provides additional support for the claim that involvement in conveyancing by lawyers adds little value. To test this hypothesis, I use a cross

\footnotetext{
24 Paz-Ares (1995, p. 48, n. 84) tells how little variation was found in the 1990s within a sample of 500 articles of incorporation constraining the alienability of company shares.

25 There are numerous accounts by notaries of this trivialization of their own work. For example, López Burniol (1994, pp. 113-149) and Berná and Crehuet (2001, especially pp. 119-122). In the same vein, from outside the profession, Paz-Ares (1995, pp. 48-49).

26 On the activities of US competition authorities counseling against restraints on lay provision of closing services, see Schechter and Wilson (2006, pp. 575-576).
} 
section of the average premiums paid for title insurance in the US, taken from Boackle (1997). The fact that more than $90 \%$ of the revenue collected by title insurers through these premiums is used to pay for their administration expenses, with only a small percentage covering insurance losses supports the interpretation of such premiums as a proxy for the cost of detecting potential title problems and, therefore, the quality provided by the conveyancing process in the long term. ${ }^{27}$

Lawyers' control of the market for preparing conveyancing documents is measured using two different independent variables. First, through the log of the number of different types of agent who are allowed to prepare documents in a given state, obtained from Boackle (1997). Second, through a dummy that takes value one for those states in which lawyers are required to prepare such documents; and takes value zero in all other states, taken from ALTA (2000).

Controls are used for the amount of insurance coverage, measured in logs; a dummy for owners' policies as opposed to lenders' policies; a dummy for the inclusion of the cost of the title search and examination in the reported premium; a dummy for the inclusion of commitment fee in the premium; the minimum length of the title search in the state, measured in years; the number of years of occupancy in adverse possession with color of title or payment of taxes required to claim title in the particular state; an estimation of the fees for recording a transfer and a mortgage, in dollars; the market share of the five biggest title insurers in the state; and two dummies taking value one for states with unregulated pricing of title insurance policies and for those states with a "file and use" regulation (in the default regulatory regime prices are subject to "prior approval", with one state under a "use and file" regime being computed as "file and use" and three states in which prices are promulgated being computed as "prior approval"). The use of most of the control variables is supported by their statistically significant correlations with the dependent variables, which show the expected signs.

Table 3 reports several model specifications for the two relevant independent variables. Given that most independent variables take the same value for all observations in each state, errors are likely to be correlated within countries. Therefore, "robust" standard errors have been estimated using states as clusters. Boackle (1997) provides ten approximate prices for owners' and lenders' title insurance policies with five different amounts of coverage (50, 100, 200, 500 and 1,000 thousand dollars) for 47 states and the District of Columbia, the four lowest amounts for Illinois, the three lowest for Indiana, and no data for Missouri (Iowa does not allow the sale of title insurance). In addition, data for some observations of the independent variables is missing. Equations (1) to (4) were obtained by deleting cases with some missing data while equations (5) to (8) use imputed values of missing observations (except for Iowa) obtained using the predictions from the best available subset of present data.

Results for the two key independent variables do not support the view that intervention by lawyers provides better quality in the preparation of documents. On the contrary, greater freedom of entry in this activity, as measured by the different types of agent allowed to perform such tasks, is associated with lower insurance premiums while lawyers' monopoly is associated with higher premiums. These results are statistically significant, considering the low number of observation clusters and the likelihood that the standard errors obtained in equations (3) and (4) are due to the missing data. The inclusion in the equations of control variables that proxy for the

${ }^{27}$ On the economic nature of title insurance, see Arruñada (2002). 
general quality of titles in each state (search length, years required for adverse possession and recording fees) makes it less likely that the results are driven by endogeneity or hidden variables related to state's title quality.

\section{Concluding remarks}

In essence, conveyancing services help parties to contract property, in rem, rights. Under the old system of private titling, such services used to include: gathering the consent of those third parties who might hold conflicting property rights on the same land, adapting the terms of exchange to the will of the parties in a way that solves their information asymmetry, and authenticating the contract. In all three of these functions, conveyancing involved substantial amounts of professional human capital and added considerable value as they all required legal and often local knowledge, as well as reputational capital.

Both of these requirements have been substantially watered down. First, lawyers and notaries have been displaced in the task of detecting title conflicts with third parties by the development of registers of rights as well as by improvements in recordation offices (in countries such as France) or the creation of additional, private "title plants" (as in the US), both of which apply some of the techniques of registration. Legal knowledge has also become less necessary for preparing each contract because contracts no longer need title guarantees, are increasingly standardized for mass transactions and mandatory law dictates many of their terms. Furthermore, large firms are in a position in which they can effectively safeguard transactions against information asymmetries without outside help. Finally, digital technology now has the potential to make traditional authentication methods obsolete.

The private and social value of legal assistance in conveyancing services has therefore been declining. Regulation should be adapted accordingly, as both the information asymmetry and externality rationales for restrictive regulation hold less and less water over time, as a consequence of market and institutional changes. Moreover, regulation should be consistent with the reduced functions required of professionals. In particular, restrictive professional licensing is less justified to the extent that comparative advantage in the provision of externalities lies now in public registers and that of overcoming information asymmetries lies with large private firms. Regulation should also be consistent in preserving or, where needed, enhancing the effectiveness of public registers.

For standard transactions, the horizon of regulation should be a sort of industrialized production of property rights with low costs and no defects. This Toyota-like manufacturing of property rights requires only a few changes in countries with properly-functioning registers: simplifying overriding interests, standardizing forms and allowing digital access to the registry. In this way, standard rights in real estate would end up being contracted as commodities, ideally in a way resembling financial derivatives, with much lower transaction costs than today.

The role of law professionals in formalizing these standard transactions would be understandably small. Recent reforms and tendencies are moving in this direction, focusing the 
use of lawyers only on those transactions for which they are really needed. In most of the US, lawyers do not intervene in residential transactions and mortgages. In most cases, title companies, through lay employees, search the title, prepare the documents and close the transaction. These tasks have been performed in England by licensed conveyancers since 1986. The fact that the US uses recording of deeds and England registration of rights shows that these changes are viable under both systems of public titling.

Liberalization does not therefore entail the disappearance of participation by lawyers and notaries, but does require them to refocus their services. Law professionals are required to tailor the high-value transactions in which such tailoring is most valuable. They are also needed for exceptional cases of lower value, but in these they participate within an organized hierarchy that filters cases, matching their complexity with the human capital of the professionals handling them. Liberalization also encourages all sorts of providers to offer additional services, including a fuller guarantee - e.g. strict liability and no-fault errors and omissions insurance - and the gathering of additional information (for instance, on the physical quality of residential real estate and zoning restrictions, which is now underprovided in many countries). Trends in countries that have been pioneers in liberalization indicate that there will also be a good deal of vertical integration, with competition amongst organizations that combine different mixes of legal, insurance, financial, distribution and mediation services in order to both reduce conflicts of interest and provide more valuable service to end users. 


\section{References}

ABA, American Bar Association (2001), Model Rules of Professional Conduct, http://www2.law.cornell.edu/cgi-bin/foliocgi.exe/modelrules, accessed June 1 $1^{\text {st }}, 2004$.

ALTA, American Land Title Association (2000), "Real Estate Closings by Non-Attorneys or Title Agents/Title Insurers," mimeo, ALTA, Washington DC.

ANDERSON, J. S. (1992), Lawyers and the Making of English Land Law, 1832-1940, Clarendon Press and Oxford University Press, Oxford and New York.

ARRUÑADA, B. (1996), "The Economics of Notaries," European Journal of Law and Economics, 3 (1), 5-37.

ARRUÑADA, B. (2000), "The Quasi-Judicial Role of Large Retailers: An Efficiency Hypothesis of their Relation with Suppliers," Revue d'Economie Industrielle, $92\left(2^{\text {nd }}\right.$ and $3^{\text {rd }}$ trimesters), 277-296.

ARRUÑADA, B. (2001), "Pasado, presente y futuro del notariado," Folio Real: Revista Peruana de Derecho Registral y Notarial, 2 (6), 135-153.

ARRUÑADA, B. (2002), "A Transaction-Cost View of Title Insurance and its Role in Different Legal Systems," The Geneva Papers on Risk and Insurance-Issues and Practice, 27 (4), 582-601.

ARRUÑADA, B. (2003a), "Property Enforcement as Organized Consent," Journal of Law, Economics, and Organization, 19 (2), 401-444.

ARRUÑADA, B. (2003b), "Vías de acceso al Registro de la Propiedad: La experiencia española" Revista Crítica de Derecho Inmobiliario, 79 (680), 3271-3289.

ARRUÑADA, B. (2006), "Managing Competition in Professional Services and the Burden of Inertia," in C.-D. Ehlermann and I. Atanasiu, eds., European Competition Law Annual 2004: The Relationship between Competition Law and the (Liberal) Professions, Hart Publishing, Oxford and Portland Oregon, 51-71.

ARRUÑADA, B., and N. GAROUPA (2005), “The Choice of Titling System in Land," Journal of Law and Economics, 48 (2), 709-727.

ARRUÑADA, B., L. GARICANO and L. VÁZQUEZ (2001), "Contractual Allocation of Decision Rights and Incentives: The Case of Automobile Distribution," Journal of Law, Economics, and Organization, 17 (1), 256-283.

BAKER, M., MICELI, T. J., C. F. SIRMANS and G. K.TURNBULL (2002), "Optimal Title Search," Journal of Legal Studies, 31 (1), 139-158.

BERNÁ, J., and E. CREHUET (2001), A l'infern de dos en dos: Cartes entre Joan Berná i Eladi Crehuet, notaris, Lérida, Pagès. 
BOACKLE, K. F. (1997), Real Estate Closing Deskbook: A Lawyer's Reference Guide \& StateBy-State Summary, General Practice, Solo and Small Firm Section, American Bar Association, Chicago.

BOSTICK, C. D. (1987), "Land Title Registration: An English Solution to an American Problem”, Indiana Law Journal, 63, 55-111.

BROCKMAN, J. (1997), “'Better to Enlist Their Support than to Suffer Their Antagonism': The Game of Monopoly between Lawyers and Notaries in British Columbia, 1930-81," International Journal of the Legal Profession, 4 (3), 197-234.

BURKE, B., and J. K. FOX (1976), "The Notaire in North America: A Short Study of the Adaptation of a Civil Law Institution," Tulane Law Review, 50, 318-345.

CLOSEN, M. L., and G. G. DIXON, III (1992), "Notaries Public from the Time of the Roman Empire to the United States Today, and Tomorrow," North Dakota Law Review, 68, 873-96.

COMMISSION OF THE EUROPEAN COMMUNITIES (2005), "Professional Services - Scope for More Reform, Follow-up to the Report on Competition in Professional Services, $\operatorname{COM}(2004) 83$ of 9 February 2004 (SEC(2005) 1064)", Communication from the Commission to the Council, the European Parliament, the European Economic and Social Committee and the Committee of the Regions, Brussels, 5 September, COM(2005) 405 final. (http://europa.eu.int/comm/competition/liberal_professions/sec200564_en.pdf, visited January 15, 2006).

CORWIN P. S. (1998), "Notaries in Cyberspace: A New Role for Banks," American Banker, 163 (27), p. 4.

DGRN, Dirección General de los Registros y del Notariado (several years), Anuario de la Dirección General de los Registros y del Notariado, Ministerio de Justicia, Madrid.

DOJ, (1999), "Letter to Board of Governors, Kentucky Bar Association," US Department of Justice, Washington DC, June 10, 1999 (http://www.usdoj.gov/atr/public/comments/3943.pdf, visited June 30, 2004).

DUKEMINIER, J., and J. E. KRIER (1998), Property, $4^{\text {th }}$ ed., Aspen Law and Business, New York.

DZIENKOWSKI, J. S. (1992), "Lawyers as Intermediaries: The Representation of Multiple Clients in the Modern Legal Profession," University of Illinois Law Review, 3, 741-817.

ELLICKSON, R. C, and C. D. THORLAND (1995), "Ancient Land Law: Mesopotamia, Egypt, Israel," Chicago-Kent Law Review, 71 (1), 321-411.

EMF, European Mortgage Federation (2006), Study on the Cost of Housing in Europe, EMF, Brussels.

HAZARD, G. C. (1978), Ethics in the Practice of Law, Yale University Press, New Haven, CT.

HOFFMAN, P. T., G. POSTEL-VINAY and J.-L. ROSENTHAL (1998), "What Do Notaries Do? Overcoming Asymmetric Information in Financial Markets: The Case of Paris 1751," Journal of Institutional and Theoretical Economics, 154 (3), 499-530.

HOFFMAN, P. T., G. POSTEL-VINAY and J.-L. ROSENTHAL (2000), Priceless Markets: The Political Economy of Credit in Paris, 1660-1870, University of Chicago Press, Chicago. 
HUD, United States Department of Housing and Urban Development (2000), "Buying Your Home: Settlement Cost and Useful Information," revised version, July 2000 (first version: June, 1997), Washington, DC.

JACOBUS, C. J. (1999), Real Estate Principles, $8^{\text {th }}$ ed., Prentice Hall, Upper Saddle River, NJ.

KAHNEMAM, D., and A. TVERSKY (1979), "Prospect Theory: An Analysis of Decision Under Risk," Econometrica, 47 (2), 263-292.

KATZ, A. (1990), "Your Terms of Mine? The Duty to Read the Fine Print in Contracts," RAND Journal of Economics, 21 (4), 518-33.

KOLBERT, C. F., and N. A. M. MACKAY (1977), History of Scots and English Land Law (based on The Principles of Scots and English Land Law by C. d' O. Farran), Geographical Publications, Berkhamsted.

KONIG, D. T. (1974), "Community Custom and the Common Law: Social Change and the Development of Land Law in Seventeenth-Century Massachusetts," The American Journal of Legal History, 18, 137-177.

KOROBKIN, R. (2003), "Bounded Rationality, Standard Form Contracts and Unconscionability," University of Chicago Law Review, 70, 1203-1295.

KUIJPERS, N., J. NOAILLY and B. VOLLAARD (2005), "Liberalisation of the Dutch Notary Profession: Reviewing its Scope and Impact," CPB Netherlands Bureau for Economic Policy Analysis, Discussion Paper, 93, September, http://www.cpb.nl/nl/pub/cpbreeksen/document/93/doc93.pdf, accessed March 7, 2006.

LÓPEZ BURNIOL, J. J. (1994), "Entre el servicio y el control: Contribución de la fe pública a la ordenación del mercado," Iuris: Cuaderns de Política Jurídica, 1, 113-149.

MALAVET, P. A. (1996), "Counsel for the Situation: The Latin Notary, A Historical and Comparative Model," Hastings International and Comparative Law Review, 19, 389-488.

MONTI, M. (2003), "Competition in Professional Services: New Light and New Challenges," Bundesanwaltskammer, Berlin, March 21.

NAHUIS, R., and J. NOAILLY (2005), "Competition and Quality in the Notary Profession," CPB Netherlands Bureau for Economic Policy Analysis, Discussion Paper, 94, September, http://www.cpb.nl/nl/pub/cpbreeksen/document/94/doc94.pdf, accessed March 7, 2006.

NYCE, C., and M. M. BOYER (1998), “An Analysis of the Title Insurance Industry,” Journal of Insurance Regulation, 17 (2), 213-256.

PALOMAR, J. D. (1999), “The War Between Attorneys and Lay Conveyancers-Empirical Evidence Says 'Cease Fire!',' Connecticut Law Review, 31 (2), 423-546.

PANCACK, K. A., T. J. MICELI, and C. F. SIRMANS (1997), "Real Estate Agency Reform: Meeting the Needs of Buyers, Sellers, and Brokers," Real Estate Law Journal, 25, 345-377.

PATERSON, I., M. FINK, and A. OGUS (2003), "Economic Impact of Regulation in the Field of Liberal Professions in Different Member States," Institute for Advanced Studies, Vienna, January, Final Report_-Part 1, http://europa.eu.int/comm/competition, accessed May 10, 2004.

PAZ-ARES, C. (1995), El sistema notarial: Una aproximación económica, Consejo General del Notariado, Madrid. 
PULling, A. (1862), A Summary of the Law and Practice Relating to Attorneys, Stevens and Haynes, London.

RAUCENT, L. (1998), Fonction et statuts des notaires, $10^{\text {th }}$ ed., Académia-Bruylant, Maison du Droit de Louvain, Louvain.

SARTON, P. (2000), Conveyancing, $3^{\text {rd }}$ ed., Macmillan, London.

SCHECHTER, M. C., and C. C. WILSON (2006), "The Learned Professions in the United States: Where Do We Stand Thirty Years After Goldfarb," in C.-D. Ehlermann and I. Atanasiu, eds., European Competition Law Annual 2004: The Relationship between Competition Law and the (Liberal) Professions, Hart Publishing, Oxford and Portland Oregon, 555-581.

SCHMID, C., G. S. LEE, S. SEBASTIAN, M. FINK and I. PATERSON (2006), "Preliminary Findings from the Ongoing Study on 'Conveyancing Services Regulation in Europe'," Centre of European Law and Politics, University of Bremen (ZERP), December 11 (paper prepared for the Conference on "The Economic Case for Professional Services Reform," European Commission, DG Competition, Brussels, December 13, 2006).

SOTO, H. de (1989), The Other Path: The Invisible Revolution in the Third World, Harper \& Row, New York.

SOTO, H. de (2000), The Mystery of Capital: Why Capitalism Triumphs in the West and Fails Everywhere Else, Basic Books, New York.

STRANDLUND, W. (2000), "Canada Respected as a Global Model for Real Estate Practices," The Scrivener, 9 (3), http://www.notaries.bc.ca/article.php3?206, accessed July 6, 2001.

SULEIMAN, E. N. (1987), Private Power and Centralization in France: The Notaries and the State, Princeton University Press, Princeton.

THALER, R. H. (1980), “Toward a Positive Theory of Consumer Choice,” Journal of Economic Behavior and Organization, 1 (1), pp. 39-60.

TROISTER, S. H., and K. A. WATERS (1996), "Real Estate Conveyancing in Ontario: A Nineties Perspective," mimeo, Lawyers' Professional Indemnity Company, Toronto.

VAN DEN BERGH, R., and Y. MONTANGIE (2006a), "Theory and Evidence on the Regulation of the Latin Notary Profession: A Law and Economics Approach," Erasmus University Rotterdam, Erasmus Competition and Regulation Institute, ECRi-report 0604, http://mediaseor.neon.estrate.nl/publications/theory-and-evidence-regulation-latin-notaryprofes.pdf, accessed November 21, 2006.

VAN DEN BERGH, R., and Y. MONTANGIE (2006b), "Competition in Professional Services Markets: Are Latin Notaries Different?," Journal of Competition Law and Economics, 2, 189214.

WILLMAN, R., and J.-F. PILLEBOUT (2002), Buying or Selling a Home: The Notary's Mission, $3^{\text {rd }}$ ed., Mémos de Conseils par des Notaires, $1^{\text {st }}$ trimester 2002, Paris.

WORLD BANK (2004), Doing Business in 2004: Understanding Regulation, World Bank and Oxford University Press, Washington DC. 
Table 1. Transaction costs of purchasing a home and taking out a mortgage to finance the purchase, as percentage of property value

\begin{tabular}{|c|c|c|c|c|c|c|c|c|c|c|c|}
\hline & \multicolumn{5}{|c|}{ Countries with registration of rights } & \multicolumn{4}{|c|}{ Countries with recording of deeds } & \multicolumn{2}{|c|}{$\begin{array}{c}\text { Averages of } \\
\text { countries with: }\end{array}$} \\
\hline & Denmark & England & Germany & Spain & Sweden & Belgium & France & Greece & Italy & $\begin{array}{c}\text { Registra- } \\
\text { tion of } \\
\text { rights }\end{array}$ & $\begin{array}{c}\text { Recording } \\
\text { of } \\
\text { deeds }\end{array}$ \\
\hline \multicolumn{12}{|c|}{ Costs related to a house purchase : } \\
\hline Solicitors' / notary fees & $0.5 \%$ & $0.4 \%$ & $0.5 \%$ & $0.4 \%$ & $0.0 \%$ & $2.2 \%$ & $1.2 \%$ & $2.2 \%$ & $2.0 \%$ & $0.36 \%$ & $1.9 \%$ \\
\hline Property registration & $0.1 \%$ & $0.1 \%$ & $0.2 \%$ & $0.1 \%$ & $0.0 \%$ & $0.0 \%$ & $0.1 \%$ & $0.5 \%$ & $3.0 \%$ & $0.1 \%$ & $0.9 \%$ \\
\hline Property taxes & $0.6 \%$ & $1.0 \%$ & $3.5 \%$ & $7.5 \%$ & $1.5 \%$ & $12.5 \%$ & $5.1 \%$ & $9.0 \%$ & $4.0 \%$ & $2.82 \%$ & $7.65 \%$ \\
\hline Other purchase costs & $0.0 \%$ & $0.1 \%$ & $0.0 \%$ & $0.0 \%$ & $0.1 \%$ & $0.0 \%$ & $0.4 \%$ & $0.0 \%$ & $0.0 \%$ & $0.04 \%$ & $0.1 \%$ \\
\hline Total purchase cost & $1.2 \%$ & $1.6 \%$ & $4.2 \%$ & $8.0 \%$ & $1.6 \%$ & $14.7 \%$ & $6.8 \%$ & $11.7 \%$ & $9.0 \%$ & $3.32 \%$ & $10.55 \%$ \\
\hline \multicolumn{12}{|c|}{ Costs related to the mortgage loan: } \\
\hline Property valuation & $0.0 \%$ & $0.3 \%$ & $0.0 \%$ & $0.1 \%$ & $0.0 \%$ & $0.1 \%$ & $0.0 \%$ & $0.1 \%$ & $0.5 \%$ & $0.08 \%$ & $0.18 \%$ \\
\hline Solicitors'/ notary fees & $0.1 \%$ & $0.0 \%$ & $0.2 \%$ & $0.4 \%$ & $0.0 \%$ & $1.6 \%$ & $0.9 \%$ & $0.0 \%$ & $2.0 \%$ & $0.14 \%$ & $1.13 \%$ \\
\hline Mortgage registration & $0.1 \%$ & $0.0 \%$ & $0.1 \%$ & $0.1 \%$ & $0.8 \%$ & $0.0 \%$ & $0.1 \%$ & $0.5 \%$ & $0.3 \%$ & $0.22 \%$ & $0.23 \%$ \\
\hline Loan taxes & $1.5 \%$ & $0.0 \%$ & $0.0 \%$ & $0.6 \%$ & $0.0 \%$ & $0.8 \%$ & $0.1 \%$ & $0.0 \%$ & $0.0 \%$ & $0.42 \%$ & $0.23 \%$ \\
\hline Other loan costs & $0.4 \%$ & $0.0 \%$ & $0.0 \%$ & $0.4 \%$ & $0.0 \%$ & $0.0 \%$ & $0.0 \%$ & $0.8 \%$ & $0.0 \%$ & $0.16 \%$ & $0.2 \%$ \\
\hline Total mortgage loan cost & $2.1 \%$ & $0.3 \%$ & $0.3 \%$ & $1.7 \%$ & $0.8 \%$ & $2.5 \%$ & $1.0 \%$ & $1.4 \%$ & $2.8 \%$ & $1.04 \%$ & $1.93 \%$ \\
\hline Total legal cost & $0.8 \%$ & $0.5 \%$ & $1.0 \%$ & $1.0 \%$ & $0.8 \%$ & $3.8 \%$ & $2.3 \%$ & $3.2 \%$ & $7.3 \%$ & $0.82 \%$ & $4.15 \%$ \\
\hline Total cost & $3.3 \%$ & $1.9 \%$ & $4.5 \%$ & $9.7 \%$ & $2.4 \%$ & $17.1 \%$ & $7.8 \%$ & $13.0 \%$ & $11.8 \%$ & $4.36 \%$ & $12.43 \%$ \\
\hline
\end{tabular}

Notes: Classification of titling systems and averages drawn up by the author from data collected by the European Mortgage Federation for typical homes and loans acquired in 2004 by first-time buyers in each country (EMF, 2006, p. 20). Data available for Hungary and Poland is not included because of the nascent nature of their titling systems but including it does not substantially modify the results. World Bank's Doing Business data is not comparable because it excludes the cost of professional services which are not legally mandatory even if they are widely used by contractual parties, who often have theoretical rather than real freedom not to retain such professionals. "Total legal cost" includes solicitors, notaries and registers. 
Table 2. Average annual output per notary in Spain, in order of increasing rates of growth of different types of document between 1970 and 1998

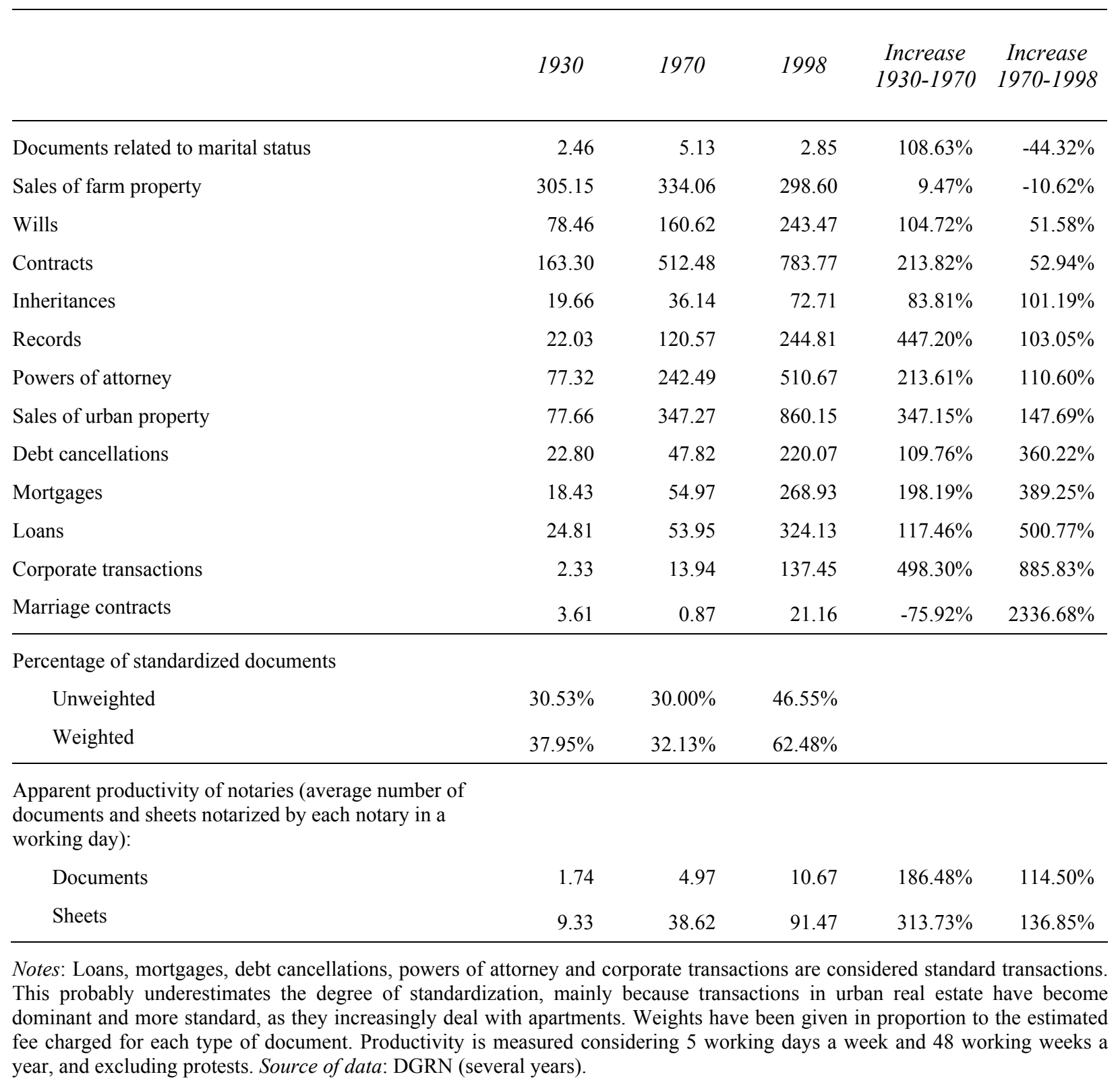


Table 3. Participation by lawyers in the preparation of conveyance documents and title insurance premiums across US states. Dependent variable: Log of state average title insurance premiums

\begin{tabular}{|c|c|c|c|c|c|c|c|c|}
\hline & $(1)$ & (2) & (3) & (4) & $(5)$ & $(6)$ & (7) & $(8)$ \\
\hline \multicolumn{9}{|l|}{ Lawyers participation in the preparation of documents: } \\
\hline $\begin{array}{l}\text { Log of the types of agent allowed to prepare documents, including } \\
\text { lawyers, parties, title companies, lenders, etc. (Boackle, 1997, question 3) }\end{array}$ & $\begin{array}{l}-0.184^{*} \\
(0.103)\end{array}$ & $\begin{array}{l}-0.193^{* *} \\
(0.092)\end{array}$ & & & $\begin{array}{l}-0.136^{* *} \\
(0.057)\end{array}$ & $\begin{array}{l}-0.151^{* *} \\
(0.060)\end{array}$ & & \\
\hline $\begin{array}{l}\text { Lawyers' monopoly in preparation of documents; } \\
=1 \text {, if monopoly; = 0, otherwise (Source: ALTA, 2000) }\end{array}$ & & & $\begin{array}{l}0.063 \\
(0.080)\end{array}$ & $\begin{array}{l}0.046 \\
(0.078)\end{array}$ & & & $\begin{array}{l}0.190^{* *} \\
(0.087)\end{array}$ & $\begin{array}{l}0.193^{* *} \\
(0.095)\end{array}$ \\
\hline \multicolumn{9}{|l|}{ Control variables: } \\
\hline $\begin{array}{l}\text { Log of insurance coverage } \\
\text { (Source: Boackle, 1997, question 31) }\end{array}$ & $\begin{array}{l}0.788^{* * *} \\
(0.022)\end{array}$ & $\begin{array}{l}0.788^{* * *} \\
(0.022)\end{array}$ & $\begin{array}{l}0.788^{* * *} \\
(0.022)\end{array}$ & $\begin{array}{l}0.788^{* * *} \\
(0.022)\end{array}$ & $\begin{array}{l}0.791^{* * *} \\
(0.019)\end{array}$ & $\begin{array}{l}0.791^{* * *} \\
(0.019)\end{array}$ & $\begin{array}{l}0.791^{* * *} \\
(0.019)\end{array}$ & $\begin{array}{l}0.791^{* * *} \\
(0.019)\end{array}$ \\
\hline $\begin{array}{l}\text { If policy is an owner's policy }=1 ;=0 \text { otherwise } \\
\text { (Source: Boackle, } 1997 \text {, question } 31 \text { ) }\end{array}$ & $\begin{array}{l}0.165^{* * *} \\
(0.036)\end{array}$ & $\begin{array}{l}0.165^{* * *} \\
(0.036)\end{array}$ & $\begin{array}{l}0.165^{* * *} \\
(0.036)\end{array}$ & $\begin{array}{l}0.165^{* * *} \\
(0.036)\end{array}$ & $\begin{array}{l}0.171^{* * *} \\
(0.034)\end{array}$ & $\begin{array}{l}0.171^{* * *} \\
(0.033)\end{array}$ & $\begin{array}{l}0.171^{* * *} \\
(0.034)\end{array}$ & $\begin{array}{l}0.171^{* * *} \\
(0.033)\end{array}$ \\
\hline $\begin{array}{l}\text { If fees include search and examination }=1 ;=0 \text { otherwise } \\
\text { (Source: Boackle, 1997, question 35) }\end{array}$ & $\begin{array}{l}0.312^{* *} \\
(0.125)\end{array}$ & $\begin{array}{l}0.364^{* * *} \\
(0.099)\end{array}$ & $\begin{array}{l}0.338^{* *} \\
(0.135)\end{array}$ & $\begin{array}{l}0.374^{* * *} \\
(0.120)\end{array}$ & $\begin{array}{l}0.399^{* * *} \\
(0.083)\end{array}$ & $\begin{array}{l}0.395^{* * *} \\
(0.082)\end{array}$ & $\begin{array}{l}0.502^{* * *} \\
(0.099)\end{array}$ & $\begin{array}{l}0.497^{* * *} \\
(0.094)\end{array}$ \\
\hline $\begin{array}{l}\text { Commitment fees added to premium }=1 ;=0 \text { otherwise } \\
\text { (Source: Boackle, 1997, question 32) }\end{array}$ & $\begin{array}{l}0.274^{* *} \\
(0.102)\end{array}$ & $\begin{array}{l}0.270^{* *} \\
(0.102)\end{array}$ & $\begin{array}{l}0.273^{* *} \\
(0.104)\end{array}$ & $\begin{array}{l}0.271^{* *} \\
(0.109)\end{array}$ & $\begin{array}{l}0.248^{* *} \\
(0.097)\end{array}$ & $\begin{array}{l}0.269^{* * *} \\
(0.099)\end{array}$ & $\begin{array}{l}0.278^{* * *} \\
(0.099)\end{array}$ & $\begin{array}{l}0.298^{* * *} \\
(0.104)\end{array}$ \\
\hline $\begin{array}{l}\text { Search length in years (Sources: Boackle, 1997, question 1; Baker } \\
\text { et al., 2002, p. 149) }\end{array}$ & $\begin{array}{l}0.003^{* * *} \\
(0.001)\end{array}$ & $\begin{array}{l}0.003^{* * *} \\
(0.001)\end{array}$ & $\begin{array}{l}0.003^{* * *} \\
(0.001)\end{array}$ & $\begin{array}{l}0.003^{* *} \\
(0.001)\end{array}$ & $\begin{array}{l}0.002^{* *} \\
(0.001)\end{array}$ & $\begin{array}{l}0.002^{* *} \\
(0.001)\end{array}$ & $\begin{array}{l}0.002^{* *} \\
(0.001)\end{array}$ & $\begin{array}{l}0.003^{* * *} \\
(0.001)\end{array}$ \\
\hline $\begin{array}{l}\text { Years required for adverse possession with color of title or } \\
\text { payment of taxes (Source: Jacobus, 1999, p. 98) }\end{array}$ & $\begin{array}{l}-0.004 \\
(0.007)\end{array}$ & & $\begin{array}{l}-0.008 \\
(0.006)\end{array}$ & & $\begin{array}{l}-0.010^{*} \\
(0.006)\end{array}$ & & $\begin{array}{l}-0.011^{*} \\
(0.006)\end{array}$ & \\
\hline $\begin{array}{l}\text { Estimated recording fees for transfer and mortgage, in } \$ \\
\text { (Source: Boackle, 1997, questions } 6 \text { and 15) }\end{array}$ & $\begin{array}{l}-0.001 \\
(0.002)\end{array}$ & & $\begin{array}{l}0.001 \\
(0.002)\end{array}$ & & $\begin{array}{l}0.002 \\
(0.001)\end{array}$ & & $\begin{array}{l}0.003^{*} \\
(0.001)\end{array}$ & \\
\hline $\begin{array}{l}\text { State market share of top five title insurance firms } \\
\text { (Source: Nyce \& Boyer, 1998, Appendix D, column C) }\end{array}$ & $\begin{array}{l}-0.007 \\
(0.006)\end{array}$ & & $\begin{array}{l}-0.006 \\
(0.007)\end{array}$ & & $\begin{array}{l}-0.009^{*} \\
(0.005)\end{array}$ & $\begin{array}{l}-0.010^{*} \\
(0.005)\end{array}$ & $\begin{array}{l}-0.009 \\
(0.005)\end{array}$ & $\begin{array}{l}-0.011^{* *} \\
(0.005)\end{array}$ \\
\hline $\begin{array}{l}\text { Unregulated pricing of title insurance } \\
\text { (Source: Nyce \& Boyer, 1998, Appendix D, column E) }\end{array}$ & $\begin{array}{l}-0.049 \\
(0.112)\end{array}$ & & $\begin{array}{l}-0.065 \\
(0.105)\end{array}$ & & $\begin{array}{l}0.012 \\
(0.077)\end{array}$ & & $\begin{array}{l}0.007 \\
(0.073)\end{array}$ & \\
\hline $\begin{array}{l}\text { "File and use" regulation of title insurance prices } \\
\text { (Source: Nyce \& Boyer, 1998, Appendix D, column E) }\end{array}$ & $\begin{array}{l}0.003 \\
(0.085)\end{array}$ & & $\begin{array}{l}-0.037 \\
(0.089)\end{array}$ & & $\begin{array}{l}0.007 \\
(0.071)\end{array}$ & & $\begin{array}{l}-0.034 \\
(0.076)\end{array}$ & \\
\hline Constant & $\begin{array}{l}-2.972^{* * *} \\
(0.762)\end{array}$ & $\begin{array}{l}-3.616^{* * *} \\
(0.307)\end{array}$ & $\begin{array}{l}-3.097^{* * *} \\
(0.730)\end{array}$ & $\begin{array}{l}-3.720^{* * *} \\
(0.293)\end{array}$ & $\begin{array}{l}-2.885^{* * *} \\
(0.552)\end{array}$ & $\begin{array}{l}-2.806^{* * *} \\
(0.510)\end{array}$ & $\begin{array}{l}-3.091^{* * *} \\
(0.527)\end{array}$ & $\begin{array}{l}-2.930^{* * *} \\
(0.494)\end{array}$ \\
\hline Observations & 340 & 340 & 340 & 340 & 500 & 500 & 500 & 500 \\
\hline Clusters & 34 & 34 & 34 & 34 & 50 & 50 & 50 & 50 \\
\hline R-squared & 0.91 & 0.91 & 0.91 & 0.90 & 0.90 & 0.89 & 0.90 & 0.89 \\
\hline
\end{tabular}

Notes: OLS regressions, observations clustered into states. Robust standard errors in parentheses. Models (5) to (8) use imputed values for 16 observations of fees (3.20\%), 40 of search time $(8.00 \%)$ and 120 of commitment fees $(24.00 \%)$. ${ }^{*}$ Significant at $10 \% ;{ }^{* *}$ significant at $5 \%$; ${ }^{* * *}$ significant at $1 \%$. 


\section{Annex}

Table A.1. Descriptive statistics for the variables used in the econometric model

\begin{tabular}{|c|c|c|c|c|c|}
\hline Variable & Observations & Mean & $\begin{array}{l}\text { Standard } \\
\text { Deviation }\end{array}$ & Minimum & Maximum \\
\hline Log of premiums & 484 & 6.579234 & .9451496 & 3.912023 & 8.83142 \\
\hline Lawyers' monopoly & 510 & .3137255 & .4644618 & 0 & 1 \\
\hline Log of types of allowed preparers & 510 & .5923906 & .5590429 & 0 & 2.70805 \\
\hline Log of coverage & 510 & 12.29669 & 1.076824 & 10.81978 & 13.81551 \\
\hline Owner's policy & 510 & .5 & .5004909 & 0 & 1 \\
\hline Fees include search & 510 & .4313725 & .4957542 & 0 & 1 \\
\hline Commitment fees & 380 & .6052632 & .4894385 & 0 & 1 \\
\hline Search length & 470 & 86.82979 & 57.08831 & 30 & 187 \\
\hline Years for adverse possession & 510 & 11.26471 & 5.412596 & 3 & 25 \\
\hline Recording fees & 510 & 54.61765 & 23.37017 & 18 & 124 \\
\hline Market share 5 top firms & 510 & 86.61176 & 7.920842 & 72.6 & 100 \\
\hline Unregulated pricing & 500 & .22 & .4146612 & 0 & 1 \\
\hline "File and use" regulation of prices & 500 & .24 & .4275109 & 0 & 1 \\
\hline
\end{tabular}

